\title{
Historia
}

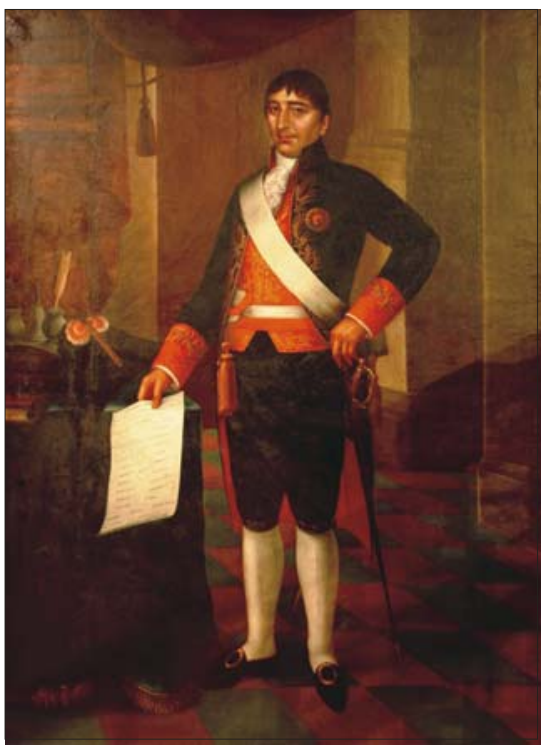

\section{Simposio: 250 años del nacimiento de Hipólito Unanue}

Hipólito Unanue, nacido en la ciudad de Arica, el 13 de agosto de 1755, es uno de los personajes más importantes en la historia del Perú. Inclinado inicialmente al sacerdocio, ingresó al Seminario de San Jerónimo de Arequipa, en donde cursó Humanidades, Filosofía y Principios de Jurisprudencia, para luego trasladarse a Lima donde pone de relieve su inclinación hacia las Ciencias Naturales. Graduado como Bachiller en Medicina, prestó juramento en 1785, en la capilla de la Real Universidad Mayor de San Marcos, obteniendo luego por oposición la Cátedra de Anatomía, siendo en 1807 Protomédico del Reino. En 1812 inicia su carrera política, siendo elegido diputado por Arequipa en las Cortes de Cádiz. En 1815 obtiene del Rey el Real Decreto que autoriza la creación del Colegio de Medicina, que a la postre se constituiría en el Real Colegio de San Fernando. Ministro de Hacienda de San Martín en 1821, Diputado por Puno en 1823, fue ministro de Hacienda e Instrucción de Bolivar y crea en 1826 la Dirección General de Beneficencia Pública. En 1826 fue presidente del Consejo de Ministros y encargado del Poder Supremo cuando Bolivar abandona el país en setiembre de dicho año. El Congreso Constituyente del Perú en virtud de sus servicios prestados a la naciente república lo declaró Benemérito a la Patria en grado eminente. Murió en Lima el 15 de julio de 1833.

Su trayectoria traspasa los linderos de la medicina peruana, de la cual es uno de sus fundadores para proyectarse a través de sus reflexiones sobre el país y sus gentes Los más importantes intelectuales peruanos, desde Jorge Basadre hasta Luis Felipe Alarco y Juan Abugattás, se han ocupado de analizar la vida y obra de alguien cuyas ideas, 250 años después de su nacimiento, siguen despertando el interés y el debate entre los intelectuales que reflexionan sobre los problemas que presenta el Perú.

Para San Fernando, heredero del proyecto de Medicina Peruana de Unanue, es un deber y obligación rendir homenaje a este ilustre pro-hombre del Perú. De alli la iniciativa de un Simposio donde se plantea nuevos aportes respecto su obra y sobre todo la proyección de sus ideas a lo largo de nuestra historia. Sin embargo, consideramos que, más que loas y exaltaciones, Unanue debe ser recordado de la misma manera como él expresó su profundo compromiso con el país, a través del debate y la reflexión sobre los problemas que tan certeramente identificó como centrales para la medicina y el Perú.

Además, consideramos que en estos tiempos de incertidumbre, debemos rescatar lo central de la experiencia de vida de Unanue, ese irreductible compromiso con el Perú y el extraordinario empuje, iniciativa y creatividad para impulsar procesos de transformación e innovaciones en las precarias condiciones materiales y sociales que impone nuestro medio y sobre todo, su entereza para enfrentar el caos e incertidumbres de los complejos y difíciles eventos que le tocó vivir y de los cuales fue un activo protagonista, en medio del colapso del régimen colonial y el nacimiento de la república.

Esa terquedad a toda prueba es, en el fondo, la certeza de los destinos superiores que le esperan a San Fernando y al Perú, que demandan, para su logro, el mismo coraje, esfuerzo y sacrificio que tan generosamente entregó Unanue al país.

Dr. José Carlos Pacheco Romero Editor "Anales de la Facultad de Medicina" 